DOI: 10.14720/aas.2016.107.2.05

Agrovoc descriptors: cereals, maize, Zea mays, varieties, drought stress, crop yield, chemical composition, lipid content, protein content

Agris category code: F06, f60, f62, q04

\title{
Changes in seed oil and protein contents of maize cultivars at different positions on the ear in response to water limitation
}

\author{
Kazem GHASSEMI-GOLEZANI ${ }^{1 *}$, Shabnam HEYDARI ${ }^{1}$, Bahareh DALIL $^{2}$
}

Received Janury 16, 2016; accepted May 06, 2016.

Delo je prispelo 16. januarja 2016, sprejeto 06. maja 2016.

\begin{abstract}
A field experiment was carried out as split-split plot in 2014 to assess the effects of four irrigation treatments (irrigations after $60,80,100$ and $120 \mathrm{~mm}$ evaporation, respectively) on oil and protein changes of maize cultivars (SC704, NS640 and DC303: Late, mid and early maturing cultivars, respectively) at different seed positions on the ear (upper, middle and lower positions on the ear). Overall, the highest seed yield was obtained from SC704, followed by NS640 and DC303 cultivars. Seed yield of all cultivars was higher at lower seed position on ear than at middle and upper parts of the ear under different irrigation treatments. The highest oil and protein yields were also recorded for seeds at lower position on the ear. Seed yield of all maize cultivars at various seed positions decreased with increasing irrigation intervals. Oil percentage decreased, but protein percentage increased with decreasing water availability. Water limitation decreased oil and protein yields of maize cultivars. Changes in protein and oil yields of maize cultivars at different seed positions and irrigation treatments were attributed to changes in seed yield.
\end{abstract}

Key words: maize cultivars, oil, protein, seed position, seed yield, water deficit

\section{IZVLEČEK}

\section{SPREMEMBE V VSEBNOSTI OLJ IN BELJAKOVIN V ZRNJU RAZLIČNIH SORT KORUZE V ODVISNOSTI OD NJIHOVEGA POLOŽAJA NA STORŽU KOT ODZIV NA POMANJKANJE VODE}

V letu 2014 je bil izveden poljski poskus z deljenkami za ovrednotenje učinkov namakanja (namakanje po 60, 80, 100 in $120 \mathrm{~mm}$ evaporacije) na spremembe $\mathrm{v}$ vsebnosti olj in beljakovin v zrnju treh sort koruze (SC704, NS640 in DC303: pozno, srednje in zgodaj dozorevajoče sorte) v odvisnosti od položaja zrnja na storža v času namakanja. Celokupno je dala največji pridelek sorta SC704, ki sta ji sledili sorti NS640 in DC303. Pridelek zrnja vseh sort je bil večji pri nižjem kot pri srednjem ali višjem položaju zrnja na storžu pri vseh načinih namakanja. Tudi največje vsebnosti olja in beljakovin so bile ugotovljene v zrnju iz spodnjega dela storža. Pridelek zrnja se je pri vseh obravnavanih sortah koruze in položajih zrnja na storžih ob namakanju zmanjševal s povečanjem presledka med namakanji. Z zmanjševanjem razpoložljivosti vode se je odstotek olja zmanjševal, beljakovin pa povečeval. Omejitev oskrbe $\mathrm{z}$ vodo je pri vseh sortah zmajšala pridelek olja in beljakovin. Spremembe v pridelku olja in beljakovin obravnavanih sort koruze pri različnih položajih zrnja na storžu ob času obravnavanj pripisujemo spremembam v pridelku zrnja.

Ključne besede: sorte koruze, olje, beljakovine, položaj zrnja na storžu, pridelek zrnja, sušni stres

\section{INTRODUCTION}

Maize (Zea mays L.) is one of the major cereals in the world with broad possibilities of use in fresh or processed form. However, the development of increasingly productive maize hybrid varieties resulted in a loss of nutritional value, especially with decreases in protein and oil, due to the negative correlation with yield (Uribelarrea et al. 2004; Bueno et al. 2009).

\footnotetext{
Department of Plant Eco-physiology, Faculty of Agriculture, University of Tabriz, Tabriz, Iran; *corresponding author: golezani@gmail.com

2 Department of Agriculture, Payame Noor Universtiy, Tehran, Iran
} 
Starch, protein and oil contents are the most important chemical storage components of maize. Maize seeds contain 70-75\% starch, 8-10\% protein and 4-5\% oil (Boyer and Hannah, 2001). The maize proteins can be divided into classes according to their solubility. In maize, the concentration of $\alpha$-zein protein is the highest, representing $50-60 \%$ of the total protein. Although the $\alpha$-zein is poor in essential amino acids such as lysine and tryptophan, the protein fractions in seeds are not constant and can vary depending on genotype (Prasanna et al. 2001).

Maize has its origin in a semi-arid area, but water deficit can limit the production of this crop (Ghassemi-Golezani et al., 1997). Drought stress inhibits the growth and development of all cultivars and hybrids of maize at different growth stages (Dai et al., 1990). Coincidence of drought stress with reproductive stages reduces duration of flowering and seed filling and consequently lowers the number of seeds per plant, mean seed mass and seed yield per unit area of common bean cultivars (Ghassemi-Golezani and Mardfar, 2008).

The final composition of the seed is known to vary by genotype and in response to the environmental conditions during seed development (Brummer et al., 1997; Westgate et al., 1999; Vollmann et al.,
2000; Yaklich et al., 2002; Fehr et al., 2003; Wilson, 2004). As the increase in the seed oil content is usually accompanied by a decrease in seed mass, the reduction in seed yield is a limiting factor to a hybrid maize with high oil content (Mišević et al. 1989). Esmailian et al. (2012) reported that water deficit at seed filling stage of sunflower caused a decrease in oil content. Drought stress imposed during seed filling decreases oil and residual contents more than the protein content (Rotundo and Westgate, 2009). This generally resulted in an increase in final protein content (Rotundo and Westgate, 2009). It is well established that water deficit shortens the seed filling duration and apparently has little impact on rate of filling (Westgate et al., 1999; Egli and Bruening, 2004).

Seed position on the ear and plant is one of the components of within-plant variation that may account for part of the variation in physical (such as mass, shape) or physiological (such as germination and vigor) seed attributes (Illipronti, 2000). However, the effect of seed position on oil and protein contents of maize is not clear, so this research was carried out to investigate the impact of irrigation levels on seed yield and composition of maize cultivars at different positions of ear.

\section{MATERIALS AND METHODS}

A split-split plot experiment (using RCB design) with three replications was conducted in 2014 at the Research Farm of the Faculty of Agriculture, University of Tabriz, Iran (latitude $38.05^{\circ} \mathrm{N}$, longitude $46.17{ }^{\circ} \mathrm{E}$, altitude $1364 \mathrm{~m}$ sea level), in order to determine the influence of water deficit on oil and protein contents of maize seeds at different ear positions. The climate is characterized by mean annual precipitation of $245.75 \mathrm{~mm}$ per year, mean annual temperature of $10{ }^{\circ} \mathrm{C}$. Irrigation treatments $\left(\mathrm{I}_{1}, \mathrm{I}_{2}, \mathrm{I}_{3}\right.$ and $\mathrm{I}_{4}$ : irrigation after $60,80,100$ and 120 $\mathrm{mm}$ evaporation from class A pan, respectively) were located in main plots, cultivars ('S.C704, 'N.S640' and 'D.C303': late, mid and early maturing, respectively) in sub plots and seed positions $\left(\mathrm{P}_{1}, \mathrm{P}_{2}, \mathrm{P}_{3}\right.$ : upper, middle and lower positions of ear, respectively) in sub-sub plots.
Seeds of maize cultivars were treated with $2 \mathrm{~g} \cdot \mathrm{kg}^{-1}$ Mancozeb and then were sown by hand on $3^{\text {rd }}$ May 2014 in $5 \mathrm{~cm}$ depth of a sandy loam soil. At the same time, plots were fertilized with $200 \mathrm{~kg} / \mathrm{ha}$ urea $(46 \% \mathrm{~N})$. Each plot consisted of nine rows of $2.5 \mathrm{~m}$ length, spaced $50 \mathrm{~cm}$ apart. All plots were irrigated immediately after sowing. Irrigation treatments were applied after seedling establishment. Hand weeding of the experimental area was carried out as required.

Ears of the maize plants from $1 \mathrm{~m}^{2}$ of the middle part of each plot were harvested when seed moisture content was 16-18\%. Seed moisture content was determined in accordance with ISTA rules (2010). Subsequently, seeds (fruitlets) were separately detached from the upper, middle and lower parts of the ears, one third each. Then, seed yield of each plot was recorded. Percentages of oil 
and protein for each sample were estimated by a seed analyzer (model: Zeltex ZX-50) and thereafter, oil and protein yields per unit area were calculated. All the data were analyzed on the basis of the experimental design, using MSTATC software. The means of each trait were compared according to Duncan multiple range test at $P \leq 0.05$. Excel software was used to draw figures.

\section{RESULTS AND DISCUSSION}

\subsection{Seed yield}

Seed yield per unit area was significantly influenced by irrigation, cultivar, position on the ear and interaction of these factors $(p \leq 0.01)$. Therefore, regression curves were fitted on mean interaction data. In general, the highest seed yield under different irrigation treatments was recorded for lower position of seeds on the ear and decreased at middle and upper parts of the ear. Seed yield of SC704 and NS640 cultivars at upper parts of ear was much lower than that of other positions. SC704 had the highest seed yield under all irrigation treatments, followed by NS640 and DC303 cultivars. Seed yield of all maize cultivars at different positions on the ear decreased with increasing water limitations. This reduction in seed yield was higher for late (SC704) and mid (NS640) maturing cultivars, compared with early maturing cultivar (DC303). These differences among cultivars were greater under well-watering and mild stress, but considerably decreased with further decrease in water availability (Fig. 1).
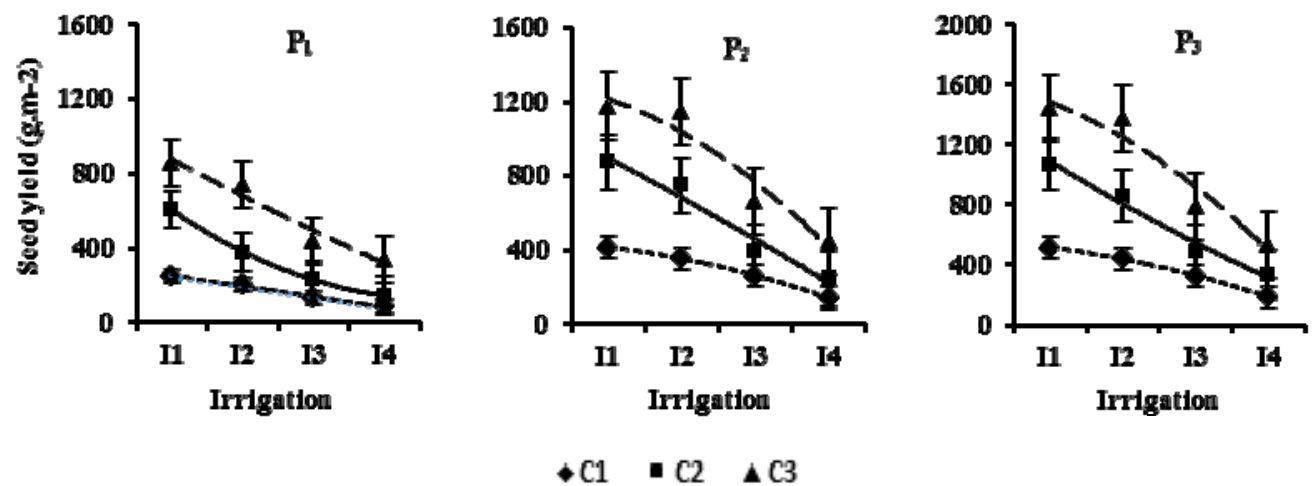

Figure 1: Changes in seed yield of maize cultivars at different positions on the ear and irrigation treatments (Means $\pm \mathrm{SE})$.

$\mathrm{C}_{1}, \mathrm{C}_{2}, \mathrm{C}_{3}$ : cultivars DC303, NS640 and SC704, respectively.

$\mathrm{P}_{1}, \mathrm{P}_{2}, \mathrm{P}_{3}$ : upper, middle and lower positions of seeds on the ear, respectively.

$\mathrm{I}_{1}, \mathrm{I}_{2}, \mathrm{I}_{3}, \mathrm{I}_{4}$ : irrigation after $60,80,100$ and $120 \mathrm{~mm}$ evaporation, respectively

\subsection{Oil percentage and yield}

Seed oil percentage and yield were significantly affected by cultivar, seed position, irrigation $\times$ cultivar and seed position $\times$ cultivar $(p \leq 0.01)$. Seed oil yield also influenced by irrigation $(p \leq 0.01)$ and seed position $\times$ irrigation $(p \leq 0.05)$. Oil percentage of late (SC704) and mid (NS640) maturing cultivars decreased with decreasing water availability, while there was no tangible change in oil percentage of early maturing cultivar (DC303) under various irrigation treatments. Mid maturing cultivar (NS640) had the highest oil percentage under all irrigation treatments, but this superiority decreased with increasing water limitations (Fig. 2a).

Increasing water deficit resulted in reduction of oil yield per unit area of all maize cultivars, but this reduction was more pronounced for late and mid maturing cultivars. Nevertheless, SC704 had the highest oil yield under all irrigation treatments, followed by NS640 and DC303 (Fig. 2b). 

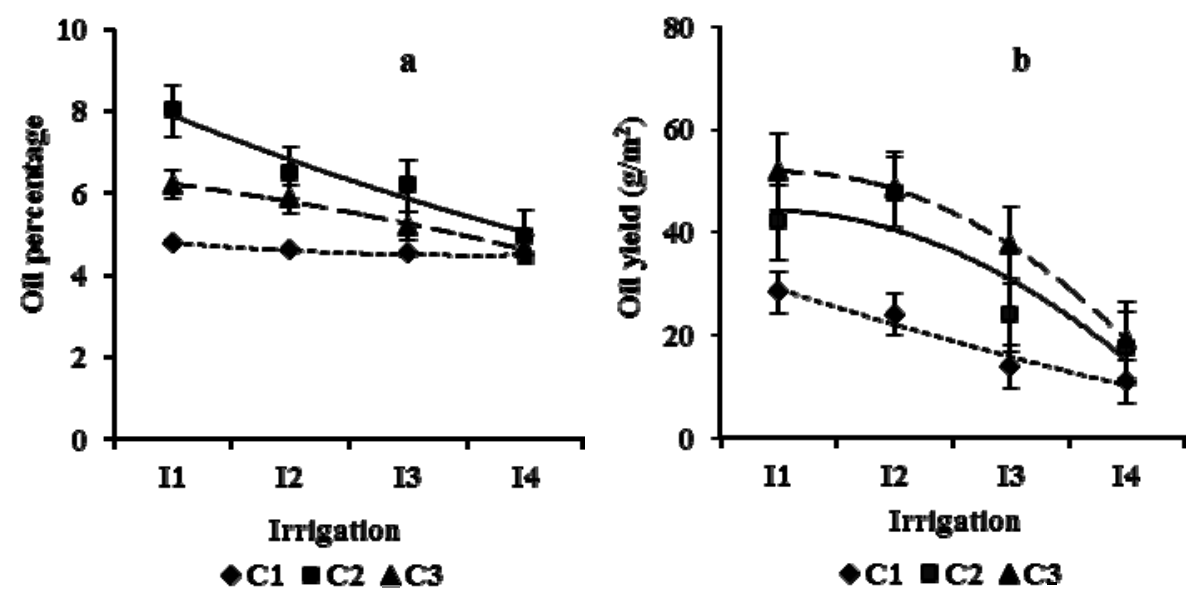

Figure 2: Changes in oil percentage (a) and yield (b) of maize cultivars at different irrigation treatments (Means \pm $\mathrm{SE})$.

$\mathrm{C}_{1}, \mathrm{C}_{2}, \mathrm{C}_{3}$ : cultivars DC303, NS640 and SC704, respectively.

$\mathrm{I}_{1}, \mathrm{I}_{2}, \mathrm{I}_{3}, \mathrm{I}_{4}$ : irrigation after $60,80,100$ and $120 \mathrm{~mm}$ evaporation, respectively

The highest oil percentage for all cultivars was obtained in seeds from lower parts of maize ear. Oil percentage of NS640 at all seed positions on the ear was higher than that of other cultivars, but this advantage was more evident at lower position on the ear $\left(\mathrm{P}_{3}\right)$. Differences in seed oil percentage of maize cultivars at middle and upper parts of the ear were minimized (Fig. 3a).

The lowest oil yield per unit area for all cultivars was recorded at upper position of seeds on the ear, which largely increased at middle and particularly at lower positions of the ear. The greatest seed oil yield at all parts of the ear was produced by
SC704, followed by mid and early maturing cultivars. These differences among maize cultivars were enhanced at lower position of seeds on the ear (Fig. 3b).

Oil yield at all seed positions decreased as water deficit increased, but the reduction rate for seeds of upper position was less than those of other positions. The highest and the lowest oil yields under all irrigation treatments were recorded for seeds of lower and upper positions of the ear, respectively. This difference decreased with decreasing water supply (Fig. 4).
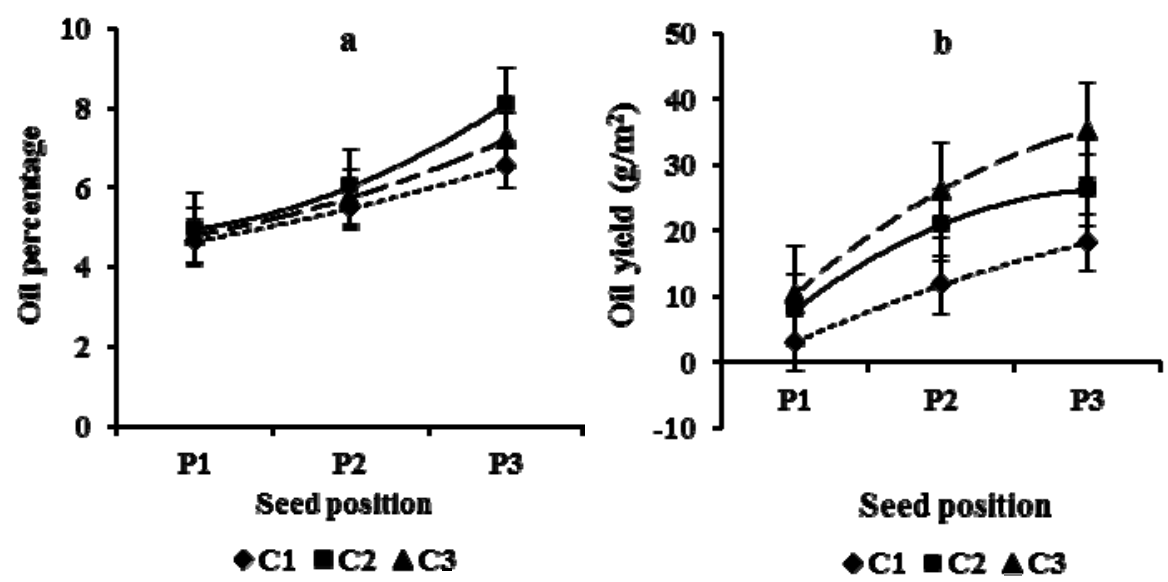

Figure 3: Changes in oil percentage (a) and yield (b) of maize cultivars at different seed positions on the ear (Means $\pm \mathrm{SE})$.

$\mathrm{C}_{1}, \mathrm{C}_{2}, \mathrm{C}_{3}$ : cultivars DC303, NS640 and SC704, respectively.

$\mathrm{P}_{1}, \mathrm{P}_{2}, \mathrm{P}_{3}$ : upper, middle and lower position of seeds on the ear, respectively. 


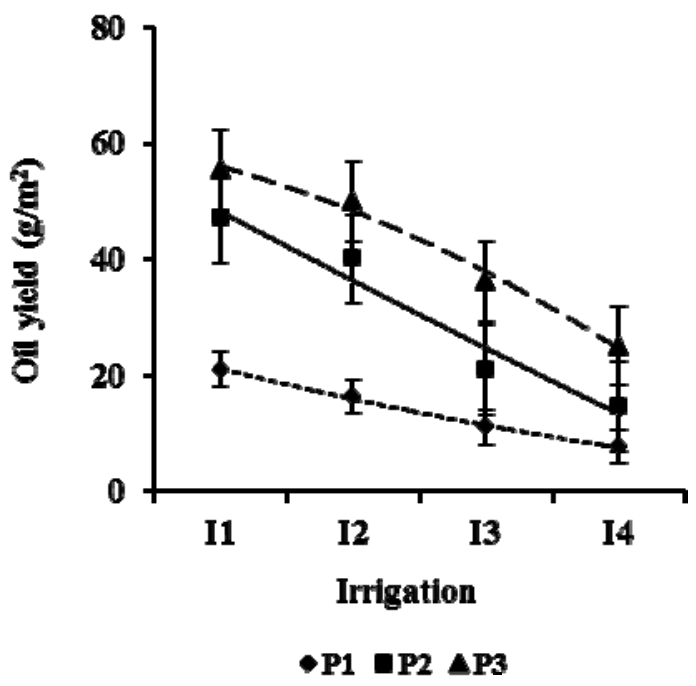

Figure 4: Seed oil yield of maize at different positions on the ear and irrigation treatments (Means $\pm \mathrm{SE}$ ). $\mathrm{P}_{1}, \mathrm{P}_{2}, \mathrm{P}_{3}$ : upper, middle and lower position of seeds on the ear, respectively. $\mathrm{I}_{1}, \mathrm{I}_{2}, \mathrm{I}_{3}, \mathrm{I}_{4}$ : irrigation after $60,80,100$ and $120 \mathrm{~mm}$ evaporation, respectively

\subsection{Protein percentage and yield}

Seed protein percentage was significantly influenced by the interactions of irrigation $x$ cultivar $(p \leq 0.05)$, seed position $\times$ cultivar and seed position $\times$ irrigation $\times$ cultivar $(p \leq 0.01)$. In contrast, seed protein yield was only affected by irrigation, cultivar, seed position and irrigation $x$ cultivar $(p \leq 0.01)$.
Mean protein percentage of maize cultivars at all seed positions on the ear increased with increasing water stress. Protein percentage of mid maturing cultivar (NS640) at all seed positions was generally higher than that of other cultivars. However, there was little difference in protein percentage of maize cultivars under severe water deficit. Seeds of upper position of all cultivars showed comparatively more protein percentage under $I_{1}$ and $I_{2}$, but this difference decreased under $\mathrm{I}_{3}$ and $\mathrm{I}_{4}$ treatments (Fig. 5).
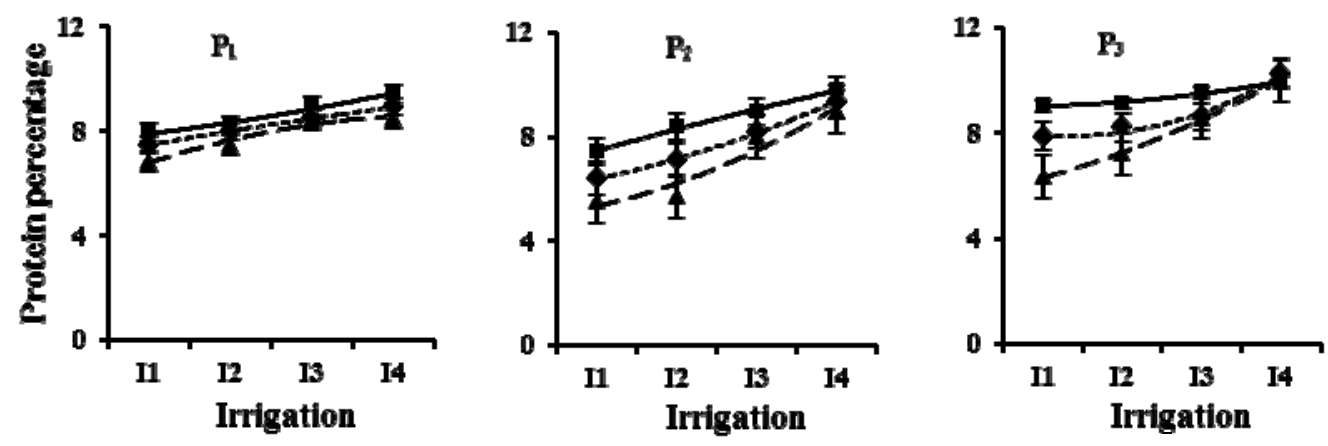

Figure 5: Changes in protein percentage of maize cultivars at different seed positions on the ear and irrigation treatments (Means $\pm \mathrm{SE})$.

$\mathrm{C}_{1}, \mathrm{C}_{2}, \mathrm{C}_{3}$ : cultivars DC303, NS640 and SC704, respectively.

$\mathrm{P}_{1}, \mathrm{P}_{2}, \mathrm{P}_{3}$ : upper, middle and lower position of seeds on the ear, respectively.

$\mathrm{I}_{1}, \mathrm{I}_{2}, \mathrm{I}_{3}, \mathrm{I}_{4}$ : irrigation after $60,80,100$ and $120 \mathrm{~mm}$ evaporation, respectively. 
Protein yield of all maize cultivars decreased as a result of drought stress. This reduction in protein yield was higher for late maturing cultivar (SC704), compared with mid (NS640) and early (DC303) maturing cultivars. SC704 had the highest protein yield under all irrigation treatments. This advantage decreased with decreasing water supply (Fig. 6a). All maize cultivars produced considerably higher protein yield at lower position of seeds on the ear, followed by mid position seeds (Fig. 6b).
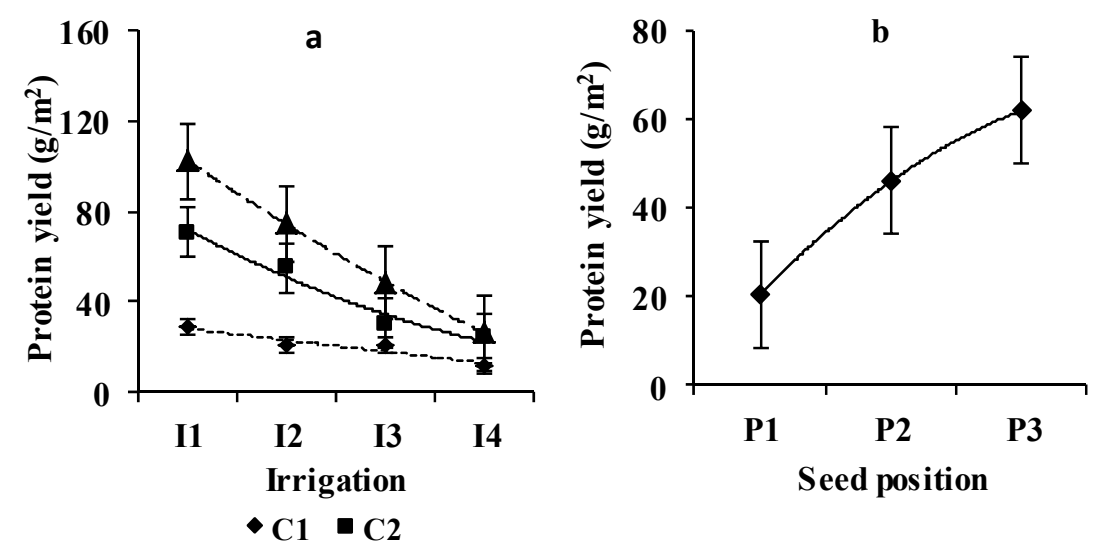

Figure 6: Seed protein yield of maize cultivars at different irrigation treatments (a) and seed positions (b) (Means \pm $\mathrm{SE})$.

$\mathrm{C}_{1}, \mathrm{C}_{2}, \mathrm{C}_{3}$ : cultivars DC303, NS640 and SC704, respectively.

$\mathrm{I}_{1}, \mathrm{I}_{2}, \mathrm{I}_{3}, \mathrm{I}_{4}$ : irrigation after $60,80,100$ and $120 \mathrm{~mm}$ evaporation, respectively

$\mathrm{P}_{1}, \mathrm{P}_{2}, \mathrm{P}_{3}$ : upper, middle and lower position of seeds on the ear, respectively.

\section{DISCUSSION}

Decreasing seed yield with increasing drought stress duration (Fig. 1) may be resulted from the short seed filling duration (Ghassemi-Golezani and Lotfi, 2013), as shown for chickpea (Davis et al., 1999), lentil (Erskine, and Ashkar, 1993), wheat (Li et al., 2000), barley (Samarah, 2005), maize (Aparicio-Tejo and Boyer, 1983), soybean (Berevedan and Egli, 2003) and sunflower (Whitfield et al., 1989). Reduced grain filling occurs due to decreased assimilate segregation and activities of sucrose and starch biosynthesis enzymes (Srivastava and Suprasanna, 2015). Drought stress occurring during seed development curtails the seed sink potential by reducing the number of endosperm cells and amyloplasts formed (Saini and Westgate, 2000), thus reducing seed mass as a result of a reduction in the capacity of the endosperm to accumulate starch (Nicolas et al., 1985). Higher seed yield at lower position of seeds on the ear (Fig. 1) was related with early formation and longer filling period of these seeds. The greater seed yield in late maturing cultivar could be attributed to longer period of radiation use and energy store of this cultivar, compared with other cultivars (Sangoi, 2000). These differences may be also influenced by the number of seeds per plant (Dalil and Ghassemi-Golezani, 2012; Ghassemi-Golezani et al., 2015).

Changes in oil and protein percentages of maize cultivars (Figs. 2a and 5) suggest that oil percentage decreases as protein percentage increases in response to water deficit. Similar results were reported for soybean under drought stress (Ghassemi-Golezani and Farshbaf-Jafari, 2012; Ghassemi-Golezani and Lotfi, 2013) and salt stress (Ghassemi-Golezani and Taifeh-Noori, 2011). It has been reported that the increase in 
protein percentage is due to reduced carbohydrate accumulation under drought stress (Mahalakshmi et al., 2006). The inverse relationship between seed protein and oil contents makes it difficult to improve both traits simultaneously (Panthee et al., 2006).

Differences in oil and protein percentages among maize cultivars indicate that these parameters can be influenced by differences in genetic constitution (Ghassemi-Golezani and Lotfi, 2013). Reductions in oil (Figs. 2b and 4) and protein (Fig. 6a) yields due to water deficit were closely related with seed yield under different irrigation treatments (Fig. 1). Variations in oil and protein production of cultivars and seeds of different positions on the ear (Figs. 3b and 6) were also largely associated with seed yield per unit area. Therefore, differences in oil and protein yields among irrigations, cultivars and seed positions on the ear could be mainly attributed to the effects of these treatments on seed yield per unit area (Fig. 1). Similarly, GhassemiGolezani and Farshbaf-Jafari, (2012) found a significant positive correlation of oil and protein yields with seed yield of soybean.

Decreasing protein yield with increasing water deficit duration (Fig. 6a) could be attributed to inhibition of nitrate absorption (GhassemiGolezani and Lotfi, 2013). It has been stated that the reduction in nitrogen uptake under drought stress conditions might be due to the reduction of absorbed water and a decrease in root permeability (Strogonov et al., 1970). However, the negative effect of water limitation on nitrogen accumulation into seeds was less than that on dry matter accumulation. Therefore, the protein percentage of seeds increased (Fig. 5), but protein yield decreased (Fig. 6a) as a result of decreasing water availability.

\section{CONCLUSION}

Late maturing maize cultivar produced the highest seed yield, followed by mid and early maturing cultivars. Seed yield of all cultivars was higher at lower position of seeds on the ear than at middle and upper parts of the ear. The highest oil and protein yields of seeds were also obtained from lower position of ears. Seed yield of all maize cultivars at various seed positions on the ear decreased with decreasing water supply. Oil percentage decreased, but protein percentage increased as water deficit severed. Drought stress decreased oil and protein yields of maize cultivars at different seed positions on the ear, mainly due to reduction in seed yield per unit area.

\section{REFERENCES}

Aparicio-Tejo, P.M., \& Boyer, J.S. (1983). Significance of accelerated leaf senescence at low water potentials for water loss and seed yield in maize. Crop Science, 23, 1198-1202. DOI:10.2135/cropsci1983.0011183X00230006004 $0 \mathrm{x}$

Berevedan, R.E., \& Egli, D.B. (2003). Short periods of water stress during seed filling, leaf senescence and yield of soybean. Crop Science, 43, 283-288. DOI: 10.2135/cropsci2003.2083

Boyer, C.D., \& Hannah, L.C. (2001). Kernel mutants of corn. In Hallauer, A.R. (ed.), Specialty corns (pp.131). Boca Raton: CRC.

Brummer, E.C., Graef, G.L., Orf, J., Wilcox, J.R., \& Shoemaker, R.C. (1997). Mapping QTL for seed protein and oil content in eight soybean populations. Crop Science, 37, 370-378.
DOI:10.2135/cropsci1997.0011183X00370002001 1x

Bueno, L.G., Chaves, L.J., Oliveira, J.P., Brasil, E.M., Reis, A.J.S., Assunçao, A., Pereira, A.F., \& Ramos, M.R. (2009). Genetic control of grain protein content and of agronomic traits in maize cultivated at different levels of nitrogen fertilization. Pesquisa Agropecuária Brasileira, 44, 590-598. DOI: 10.1590/S0100-204X2009000600007

Dai, J.Y., Gu, W.L., Shen, X.Y., Zheng, B., Qi, H., \& Cai, S.F. (1990). Effect of drought on the development and yield of maize at different growth stages. Journal of Shenyang Agricultural University, 21, 181-185.

Dalil, B., \& Ghassemi-Golezani, K. (2012). Changes in leaf temperature and grain yield of maize under

Acta agriculturae Slovenica, 107 - 2, september 2016 
different levels of irrigation. Research on Crops, $13,481-485$.

Davis, S., Turner, N.C., Siddique, K.H.M., Leport, L., \& Plummer, J. (1999). Seed growth of Desi and Kabuli chickpea (Cicer arietinum L.) in a short season Mediterranean-type environment. Australian Journal of Experimental Agriculture, 39, 181-188. DOI: $10.1071 /$ EA98134

Egli, D.B. \& Bruening, W.P. (2004). Water stress, photosynthesis, seed sucrose levels and seed growth in soybean. Journal of Agricultural Science, 142, 1-8. DOI: $10.1017 / \mathrm{S} 0021859604004095$

Erskine, W., \& Ashkar, F.E. (1993). Rainfall and temperature effects on lentil (Lens culinaris Medik) seed yield in Mediterranean environments. Journal of Agricultural Science, 121, 347-354 :Doi. $10.1017 / \mathrm{S} 0021859600085543$

Esmailian, Y., Sirousmehr, A.R., Asghripour, M.R. \& Amiri, E. (2012). Comparison of Sole and Combined Nutrient Application on Yield and Biochemical Composition of Sunflower under Water Stress. International Journal of Applied Science and Technology, 3, 214- 220.

Fehr, W.R., Hoeck, J.A., Johnson, S.L., Murphy, P.A., Nott, J.D., Padilla, G.I. \& Welke, G.A. (2003). Genotype and environment influence on protein components of soybean. Crop Science, 43, 511514. DOI: $10.2135 /$ cropsci2003.0511

Ghassemi-Golezani, K., Bakhshi, J., \& Dalil, B. (2015). Rate and duration of seed filling and yield of soybean affected by water and radiation deficits. Acta agriculturae Slovenica, 105, 225 - 232. DOI: 10.14720/aas.2015.105.2.05

Ghassemi-Golezani, K., \& Farshbaf-Jafari, S. (2012). Influence of water deficit on oil and protein accumulation in soybean grains. International Journal of Plant, Animal and Environmental Sciences, 4, 2341-2345.

Ghassemi-Golezani, K., \& Lotfi, R. (2013). Influence of water stress and pod position on oil and protein accumulation in soybean seeds. International Journal of Agronomy and Plant Production, 4, 2341-2345.

Ghassemi-Golezani, K., \& Mardfar, R.A. (2008). Effects of limited irrigation on growth and seed yield of common bean. Journal of Plant Sciences, 3, 230-235. DOI: 10.3923/jps.2008.230.235

Ghassemi-Golezani, K., Soltani, A., \& Atashi, A. (1997). The effect of water limitation in the field on seed quality of maize and sorghum. Seed Science and Technology, 25, 321-323.
Ghassemi-Golezani, K., \& Taifeh-Noori, M. (2011). Soybean performance under salinity stress. In TziBun, N. (ed). Soybean: biochemistry, chemistry and physiology. InTech, available from: http://www.intechopen.com.

International Seed Testing Association. (2010). International rules for seed testing. Seed vigor testing. Chapter 15, 1-20.

Illipronti, J.R.R.A., Lommen, W.J.M., Langerak, C.J. \& Struik, P.C. (2000). Time of pod set and seed position on the plant contribute to variation in quality of seeds within soybean seed lots. Netherlands Journal of Agricultural Sciences, 48, 165-180. DOI: 10.1016/S1573-5214(00)80012-3

Li, A.G., Hou, V.S., Wall, G.W., Trent, A., Kimball, B.A., \& Printer, B.J. (2000). Free-air CO2 enrichment and drought stress effect on seed filling rate and duration in spring wheat. Crop Science, 40, 1263-1270. DOI:10.2135/cropsci2000.4051263x

Mahalakshmi, V., Subramanian, V., Bidinger, F.R., \& Jambunathan, R. (2006). Effect of water deficit on yield and protein content in pearl millet grains. Journal of Science of Food and Agriculture, 36, 1237-1242. DOI: $10.1002 /$ jsfa.2740361206

Mišević, D., Marić, A., \& Alexander, D.E. (1989). Population cross diallel among high oil populations of maize. Crop Science, 29, 613-617. DOI: 10.2135/cropsci1989.0011183X002900030012x

Nicolas, M.E., Lambers, H., Simpson, R.J., \& Dalling, M.J. (1985). Effect of drought on metabolism and partitioning of carbon in two wheat varieties differing in drought-tolerance. Annals of Botany, $55,727-747$.

Panthee, D.R., Pantalone, V.R., \& Saxton, A.M. (2006). Modifier QTL for fatty acid composition in soybean oil. Euphytica, 152, 67-73. DOI: 10.1007/s10681-006-9179-3

Prasanna, B.M., Vasal, S.K., Kassahun, B., \& Singh, N.N. (2001). Quality protein maize. Current Science, 81, 1308-1319.

Rotundo, J.L., \& Westgate, M.E. (2009). Meta-analysis of environmental effects on soybean seed composition. Field Crops Research, 110, 147-156. DOI: $10.1016 /$ j.fcr.2008.07.012

Samarah, N.H. (2005). Effects of drought stress on growth and yield of barley. Agronomy for Sustainable Development, 25, 145-149. DOI: 10.1051/agro: 2004064

Saini, H.S., \& Westgate, M.E. (2000). Reproductive development in grain crops during drought. 
Advances in Agronomy, 68, 59-95. DOI: $10.1016 / \mathrm{S} 0065-2113(08) 60843-3$

Sangoi, 1. (2000). Understanding plant density effects on maize growth and development: an important issue to maximize grain yield. Ciência Rural, 31, 159168. doi.org/10.1590/S0103-84782001000100027

Srivastava, A.K., \& Suprasanna, P. (2015). Redoxregulated mechanisms: implications for enhancing plant stress tolerance and crop yield. In Pandey, K. (ed.), Elucidation of abiotic stress signaling in plants: functional genomics perspectives (pp. 191205). New York, Springer. Doi: 10.1007/978-14939-2211-6 7

Strogonov, B.P., Kabanov, V.V. \& Pakova, M.M. (1970). Feature of protein and nucleic acid metabolism during formative changes in plant under salinization conditions. Soviet Plant Physiology, 17, 394-397. DOI: 10.4236/cellbio.2014.31002

Uribelarrea, M., Below, F.E., \& Moose, S.P. (2004). Seed composition and productivity of maize hybrids derived from the Illinois protein strains in response to variable nitrogen supply. Crop Science, 44, 1593-1600. DOI: 10.2135/cropsci2004.1593

Vollmann, J., Fritz, C.N., Wagentristl, H., \& Ruckenbauer, P. (2000). Environmental and genetic variation of soybean seed protein content under Central European growing conditions. Journal of the Science of Food and Agriculture, 9, 1300-1306. DOI: 10.1002/1097-0010(200007)

Westgate, M.E., Piper, E., Bartchelor, W.D., \& Hurburgh, C. (1999). Effects of cultural and environmental conditions during soybean growth on nutritive value of Soy products. In, Drackley, J.K. (Ed.), Soy in animal nutrition (pp. 75-89). Chicago: Federation of Animal Science Societies.

Whitfield, D.M., Connor, D.J., \& Hall, A.J. (1989). Carbon dioxide balance of sunflower subjected to water stress during grain-filling. Field Crops Research, 20, 65-80. DOI: 10.1016/03784290(89)90024-5

Wilson, R.F. (2004). Seed Composition. In Boerma, H.R., \& Specht, J.E. (Eds.), Soybeans: improvement, production and users (pp. 621-669). Madison: American Society of Agronomy, Inc.

Yaklich, R.W., Vinyard, B., Camp, M., \& Douglass, S. (2002). Analysis of protein and oil from soybean northern and southern region uniform tests. Crop Science, 42 , 1504-1515. 